\title{
Detlef Schwefel
}

\section{International health in a globalized development perspective}

Received: 27 August 2003 / Accepted: 4 November 2003 / Published online: 3 April 2004

(C) Springer-Verlag 2004

\begin{abstract}
Eleven issues highlight the relation between globalization and health:
\end{abstract}

1. Globalization endangers health. Risks are spreading. AIDS and SARS are examples.

2. Global alliances are emerging to protect health, especially fighting AIDS, malaria and tuberculosis.

3. In many millennium declarations, health was declared a worldwide development goal.

4. The international development cooperation for health is ailing everywhere despite three good reasons to make health a priority.

5. Good health supports good politics and national security.

6. The lack of security in health is an essential trap of poverty and increases population growth.

7. Health has essential macroeconomic benefits. Leading economists have made this clear.

8. Thus, health and education are true keys to social and economic development. Brains and bodies are the most essential factors of production.

9. "Empowerment in security creates opportunities". This new motto underlines the strategic importance of health literacy and social health insurance.

10.

International or global health is a leitmotiv of this decade of development.

11.

Globalization requires powerful ethics to gain a human face. Professional ethics and a rebellious civil society ought to be allies.

Current globalization is both a threat and a positive challenge, indeed.

D. Schwefel $(\bowtie)$

Pestalozzistr. 68, 10627 Berlin, Germany

e-mail: detlef.schwefel@berlin.de

Tel.: +49-30-31802723

Fax: $+49-30-31806990$
Keywords International health $\cdot$ Health policy . Development policy

\section{Globalization endangers health}

Globalization brings opportunities and threats, profits and risks, wealth and poverty. One-fourth of the world population has become better off in the last 20 years, one-fifth is now poorer than before (Wissenschaftlicher Beirat 1999). Only 475 families own $50 \%$ of the world's wealth (Mies 2001). A total of 2.8 billion people still have to live and try to survive with less than U.S. \$2 a day. "A majority of them feel worse off and more insecure than in the past" (Wolfensohn 2000). "In a rapidly globalizing world the social ills associated with poverty-disease, illicit migration, environmental degradation, crime, political instability, armed conflict and terrorism-can spread with greater ease across borders and continents" (OECD 2001).

Health and health care are affected by globalization as well. Risk factors and communicable diseases spread more easily. Unhealthy consumption and lifestyles are being promoted through a world market of consumer goods and globalized promotion and mass media, and increase non-communicable diseases (Schwefel 2003). Environmental risks are exported and spreading worldwide. New bacteria and viruses are emerging - at least 29 new ones have been counted since 1973, HIV/AIDS being just one of them - and the old ones are getting resistant (World Health Organization 1998). The globalization of these threats has been coined the "third demographic transition" (Barrett 1998).

Internationalization of health care and especially a globalized trade with quality drugs from patent-protected transnational corporations will not solve the problem, since the world's poor with its disproportionate high disease burden can rarely afford them. Paying patentprotected prices for the intellectual property rights of new drugs and vaccines is even difficult in rich countries. Well-trained personnel are drained away from poor 
countries and regions; $35 \%$ of African health personnel is already working abroad (Sachs et al. 2001). Nevertheless, there are opportunities and alliances to use globalization to benefit health and health care.

\section{Global private-public partnerships are emerging to protect health}

Global alliances of public and private agencies are emerging and fighting for affordable and effective drugs and vaccines against AIDS, tuberculosis, malaria, which are now also threatening Western populations (Reich 2002). Kaul calls it a "flurry of policy innovations" (Kaul 2001) and points out the Global Alliance for Vaccines and Immunization (GAVI), International AIDS Vaccine Initiative (IAVI), Medicines for Malaria Venture (MMV), and the Malaria Vaccine Initiative (MVI). Additionally, at the turn of the millennium a mighty global fund for health was called for by the United Nations. It was converted into a global several-billion-dollar fund against the aforementioned specific diseases (Global Fund 2003). The same happened with the recommendations of the Commission on Macroeconomics and Health for the World Health Organization (WHO) (Sachs et al. 2001).

They all seem to have forgotten the unfinished agenda of the poor man's diseases. Under-nutrition and malnutrition and poor water and sanitation still account for many more lives lost from escapable and avoidable deaths than the much too high death tolls by malaria, tuberculosis and HIV/AIDS (World Bank 1997; Gwatkin 2000). "Lacking market power, the diseases of the poor are 'orphaned' by benign neglect" (Chen 1999).

Nevertheless, such global partnerships of private individuals such as Bill and Melinda Gates and public institutions such as WHO and the World Bank are important alliances for strengthening international health. In the public interest they pledge for the provision of public goods by enlightened leaders, since the global market economy is neglecting public health and producing public evils. Good governance, stewardship and pro-poor approaches are being increasingly requested (Murray and Frenk 2000; Saltman and Ferroussier-Davis 2000). In times of a Leviathan world market and Lilliputian national governments and in view of too many questionable regimes throughout the world, good governance is a dream or a vision to provide and guarantee public goods, health and health care being one of those public goods. The German Federal Ministry for Economic Cooperation and Development (BMZ) is in the forefront of the good governance movement (BMZ 2002).

\section{Health was declared a worldwide development goal}

The leading statesmen of the world-the so-called G7, or G8 if Russia is included-have started acting, or at least speaking in the global interest for the global provision of public goods. In the year 2000 in Okinawa, for example, they solemnly praised their leadership and for the first time included health in their agenda: "Health is the key to prosperity. Good health contributes directly to economic growth whilst poor health drives poverty. Infectious and parasitic diseases, most notably HIV/AIDS, TB and malaria, as well as childhood diseases and common infections, threaten to reverse decades of development and to rob an entire generation of hope for a better future. Only through sustained action and coherent international cooperation to fully mobilize new and existing medical, technical and financial resources, can we strengthen health delivery systems and reach beyond traditional approaches to break the vicious cycle of disease and poverty" (G8 2000).

Such declarations reached their peak at the turn of the millennium. In preparation for this event, the Organization for Economic Cooperation and Development (OECD) of the rich countries of the world had prepared and had its member states accept the so-called International Development Goals (OECD 2001):

- Reduce by half the proportion of people living in extreme income poverty (living on less than U.S. \$1 a day).

- Ensure universal primary education.

- Eliminate gender disparity in primary and secondary education (by 2005).

- Reduce infant and child mortality by two-thirds.

- Reduce maternal mortality by three-quarters.

- Ensure universal access to reproductive health services.

- Implement national strategies for sustainable development in every country by 2005 , so as to reverse the loss of environmental resources by 2015 .

These goals plainly and firmly put basic education and basic health in the very centre of the development agenda, in the context of a healthy environment and an economy that favours the poor. Protecting health, with education as the most fundamental input, and addressing the risks of sustainable social and ecological development ought to be a primary concern of the world's leaders. The United Nations, in its Millennium Goals declaration included a total of eight goals, 18 targets and 48 development indicators, $29 \%$ of which are related directly or indirectly to health (UN 2000). Health is on the international political agenda. Health and education ought to be strengthened, first to give development a more human face: this is the main millennium message.

Cause-oriented pressure groups of a globalizing civil society-like Médecins sans Frontières, Oxfam, and Greenpeace-support such pledges with a louder voice and increasing power even if, for the time being, it seems as if the health of whales, dolphins and otters is a more attractive topic for civil society movements. The international millennium poll of the United Nations reinforced the truism that health is the most important human desire, worldwide (UN 2000). Health, at the same time, is one of 
the fundamental public goods with negative impacts if not provided properly.

\section{Public spending for health is ailing}

Public funds from rich countries for strengthening basic social services in poor countries-i.e. especially health, education and the family's immediate environment such as water and sanitation-are nevertheless scarce. Independent researchers diagnosed decreasing trends of the German development cooperation in this area down to $13.5 \%$ of new commitments (Fues 2000). A peer review of the Development Assistance Committee of OECD discovered that real German spending is only $2 \%$ for basic education, $2 \%$ for basic health services and less than $3 \%$ for basic water services (OECD 2001). This seems to be consistent with a poverty reduction strategy of the German Ministry for Economic Cooperation and Development (BMZ) that comprises a very broad patchwork of ideas and interests from all consulted German ministries (BMZ 2001).

The relative neglect of basic social services and basic public goods may be explained by a weak conceptual defence for these very sectors. Bureaucrats and even advocates still consider health to be consumption and even a luxury good rather than a public investment, the health sector has a technocratic and biomedical image, its main target groups are not the productive people but the very young and the elderly, poor and even rich countries would have other priorities as can be seen in their national budgets and they would need first and foremost capital and income to strengthen consumption later. Spending for public health in rich countries follows a similar pattern and justification. Competing for scarce national resources, health and public health are getting low allocations.

These realities and the reasoning behind them ensure that development and growth could be endangered if human brains and bodies-education and health-are not recognized as the most basic foundations of development. This knowledge is now being produced and spread internationally by the world's elite in social, economic and health sciences with three main topics:

- Health and politics

- Health and poverty

- Health and production

\section{Health and politics: good health supports politics and security}

Powerlessness, instability and loss of freedoms cause diseases. This is shown by the high spread of AIDS in those areas of political conflict and unrest where women are even more powerless than elsewhere (Vandemoortele 2001). Poor public health and poor health in larger segments of society is an indicator of state failure. A lack of health care and human rights-on the other hand-can cause a country's failure. For the USA's Central Intelligence Agency (CIA), 113 cases of state failure over 38 years in countries with over half a million inhabitants were analysed and three aspects could be isolated with predictive power for incumbent state failure: high infant mortality, low democratization and low openness for international trade (State Failure Task Force 1999). The Council of Foreign Relations of the USA together with the Milbank Memorial Fund concluded: "The United States can gain significant domestic and international advantages by placing health squarely on its foreign policy agenda. Supporting public health worldwide will enhance U.S. national security, increase prosperity at home and abroad, and promote democracy in developing countries and those in transition" (Kassalow 2001). Universal and social human rights have to be supported even against governmental interests, in the best self-interest of a global community. Global interests require a strengthening of basic social and health services and even work in the interest of the wealthy countries.

Hitherto most often it was argued that health is a human right and that therefore governments and states should support health. This was one of the strong political issues in favour of health, which still holds true. But only a few countries support the idea-and realize it - that health and education shall be guaranteed by law and law enforcement for everyone in society. Germany still is that old fashioned with its nearly universal coverage of a social health insurance and the inclusion of nearly complete services for nearly all complaints. It is an offspring of a social market economy, which intends to cover basic needs for all, based on solidarity and subsidiarity. Solidarity is incorporated, for example, in the income-based premiums for about $90 \%$ of the German population. Subsidiarity is shown in the fact that public legal corporations run the business and that these corporations are democratically elected. Sustainability, nevertheless, will require a strengthening of the subsidiarity principle in the sense that people must take basic health (care) into their own hands. Health is not only the state's responsibility, but also a responsibility that rests on the people. Thus, such a patterning of health affairs is based on values and principles - the health sector in Germany is a very interesting policy area with structural implications and messages for other sectors. Solidarity and subsidiarity could pattern other policies, as well. This could support a global structural policy that creates, stabilizes and protects the very preconditions for a healthy and stable global society.

Good governance and stewardship are usually desired in a sense of a deus ex machina, i.e. that all of a sudden a politician should slip into the role of a practicing philosopher and act according to the moral imperative of Immanuel Kant. Political systems based on sustained solidarity and subsidiarity confront this naïve idea with good governance and stewardships at many levels and governed inbuilt checks and balances. The utopian idea would be that everybody would act as a steward of good governance. This requires good health (care) and good education for all as pre-investments. An empowered and 
enlightened population-"empowerment at the grassroots" (Bloom and Canning 2001) - is a strong backbone for a self-sustained and healthy society, for bottom up rather than top down policies and health policies. Health and good politics are very closely related.

\section{Health and poverty: a lack of security in health is a fundamental trap of poverty}

Poverty eradication was the catch word of the many political declarations at the turn of the millennium. As many as 1.2 billion people are extremely poor with less than U.S. $\$ 1$ daily and altogether 2.8 billion people live on less than U.S. \$2 a day. Poverty attacks health and produces disease. The vicious circle between poverty, infection, and malnutrition still exists on a large scale. This is the so-called unfinished agenda in international health. About 200 million life years are lost yearly because of malnutrition and 85 million life years resulting from poor water and sanitation (World Bank 1997). Many other diseases are directly linked to poverty. Poor countries have difficulties in tackling these diseases: $11 \%$ of global health spending goes for $93 \%$ of the global disease burden (Gwatkin 2000). Private and public poverty coincide in a context of tremendous income inequalities.

The internationally agreed development goals claim to halve extreme poverty by the year 2015 . Simply increasing income would not suffice, because of widespread lack of empowerment and because of the many life shocks that the poor experience, which quite often absorb any additional income. On behalf of the World Bank, more than 60,000 poor in more than 60 countries were interviewed in an attempt to understand poverty. The book series Voices of the poor is a very remarkable background document of the millennium declarations (Narayan 1999, 2000). Analysing carefully its content, it turns out that severe illness or accidents of family members can drain away any savings intended to be used for small entrepreneurial activities or for other emergencies. Solidarity within larger family networks absorbs any additional income. In India, for example, $25 \%$ of hospitalized patients' families fall into poverty from medical costs (Peters et al. 2002). High private expenditures of some hospitalizations even throw middle class families into poverty if there is no social security net for health care. Good health insurance and hospital coverage for the poor are the preconditions necessary to develop and support family subsistence initiatives and small scale enterprises, which are needed urgently in view of increasing unemployment and underemployment in times of globalisation and resulting shrinking labour markets.

A social security system for families' health risks reduces population growth considerably. The higher the mortality risks for children are, the exponentially higher the fertility rates will be to ensure that some of the surviving children will provide a safety net for their parents in old age. Having larger families is a form of private insurance, but it is insurance with a low efficiency. "Societies with high rates of infant mortality (deaths under 1 year of age) and child mortality (deaths under 5 years of age) have higher rates of fertility, in part to compensate for the frequent deaths of children. Large numbers of children, in turn, reduce the ability of poor families to invest heavily in the health and education of each child, a process described by Gary Becker and colleagues as the 'quality-quantity tradeoff' in child rearing" (Sachs et al. 2001). Larger families are considered to be a result of and a risk factor for poverty. The smaller the families are the higher their human capital is. The vicious circle of poverty, ignorance and disease can be turned into a beneficial link between education, health and wealth, at the microeconomic level of families and at the macroeconomic levels of regions and countries.

\section{Health and production: health has essential macroeconomic benefits}

Traditionally, money capital is considered to be the driving force of economic development, whereas health would increase population growth and strain public services and investments with high returns. This traditional wisdom was challenged recently by a Commission on Macroeconomics and Health, established by the World Health Organization to reassess the relationship between health and economic development. The commission and its many working groups assessed the available evidence on health and production and concluded that investments in health bring incredible economic returns. Scaling up essential health interventions in low-income countries with U.S. $\$ 66$ billion would bring a return of U.S. $\$ 360$ billion per year and possibly much more by the years 2015-2020 (Sachs et al. 2001). The macroeconomic benefit of fighting communicable diseases, especially, is very much higher than the costs.

Convincing evidence on the relationship between health (as input) and economic development (as outcome) abound: (Sachs et al. 2001)

- The historical development of England was supported significantly by public health measures and by improved health and nutrition (Fogel 1997) vs the conception that economic development triggers quasi automatic improved health (McKeown 1976).

- The economic rise of the Southeast Asian tiger states is explained for at least one-third by investments in health, as is their smooth fall in times of macroeconomic turbulence. Investments in education, housing and other social arrangements added to this health-led development.

- Many case studies from developing and transition economies after economic crises hint at the important pre-investments in health and education for subsequent economic growth; Sweden, Kerala and Costa Rica benefited from health-driven developments, whereas 
economy-driven developments such as in Brazil, India and Pakistan did not substantially benefit the poorest.

- The African American population in the USA enjoys relatively high income levels and-as compared to much poorer populations in China and Kerala-low survival prospects. "It turns out that Chinese men and those in Kerala in India decisively outlive American black men in terms of surviving to older age groups" (Sen 1999).

- Macroeconomic shocks in Mexico, Argentina, Brazil and especially in Central Asia had very negative impacts on health because of lacking pre-investments in health and education. The excess mortality in Russia, Belarus, and Ukraine between 1990 and 2000 was at 4 million people (Cornia 2001).

- Finally, many econometric studies show that health is a long-term driver for economic growth. Countries with a high position in the human development index subsequently experience robust and stable economic growth. Countries with low infant mortality rates produce a threefold time-lagged economic growth.

The correlation between economic growth and health - this is the traditional line of reasoning on the relationship between economics as input and health as outcome-is mainly mediated through eventually increasing incomes of the poor and expenditures on public health (Sen 1999).

\section{Health and education are the true keys to development}

Jeffrey Sachs, the outspoken world economist and chair of the macroeconomics commission concludes:

- "The evidence is overwhelming that investments in health pay off. They pay off in controlling disease, in improving productivity of the workforce, in speeding up economic growth, and in fostering social and political stability" (Sachs 2002).

- "The weight of the evidence strongly shows that investments in public health should be placed at the very center of the economic development strategy, alongside investments in education" (Sachs 2001a).

- "We have to get serious about public health in the poor countries if we are to be serious about economic development" (Sachs 2001b).

- "The international response to the heavy disease burden in the poor countries has been shockingly, indeed scandalously insufficient" (Sachs 2001b).

- "What we have is the evidence. That is why the most important thing we can do is to speak very clearly and plainly about what the evidence shows, and push the case" (Sachs 2001b).

Gro Brundtland, the former WHO general director, reinforced this idea: "Good health is not just a good in its own right, but one of the most powerful development strategies at our disposal" (Brundtland 2001).

This knowledge is spreading now throughout the world. One example from a British government think tank: "At the macro level, human development, and the demographic transition from high fertility and mortality to low fertility and mortality that is its consequence, is now widely accepted as a central long-term driver of economic growth" (Cabinet Office, Performance and Innovation Unit 2001). And another one from a German generalist in international development: "The keys to development are education and health" (Nuscheler 2001).

\section{Health empowerment in security creates opportunities}

Health is not merely the absence of diseases, nor is it just physical, mental and social well-being. The gap between well-being and well-doing has to be bridged. According to a more active understanding, health is the capacity and commitment to live and to enjoy a socially and economically productive life, with at least three components:

- The physical capacity and commitment to survive diseases and to enjoy living

- The mental capacity and commitment for informed self-help and a reasonable self-responsibility

- The social capacity and commitment, to (re)construct healthy living and environmental conditions together with families, neighbours and communities (Schwefel 2002)

In the international health discussion, mental health only recently has been rediscovered as an important part and parcel of health and as a key to physical health (WHO 2001). These capabilities are to be shaped by culture and socialization, and supported by education and training. Health and education are the very production factors for development. "Development has to be primarily concerned with enhancing the lives we lead and the freedoms that we enjoy. And among the most important freedoms that we can have is the freedom from avoidable ill-health and from escapable mortality" (Sen 1999). The goal of development is not the absence of diseases but to use brain (education) and body (health) rightly to improve our lives, living conditions and freedoms. This would be a bottom-up development. Health and education-bodies and brains - are not just any factor of production but the most essential human factors of production and development.

The World Bank's World Development Report 2000/ 2001 (2001) conceptualized three pillars for attacking poverty: empowerment, security and opportunities. With a slightly different meaning and linking these components functionally, they can show a new direction for reasonable interventions in health: the empowerment of people 
in a situation of security creates opportunities for development.

- "Empowerment is based on:

a. Programmes to strengthen subsidiarity, e.g. through building up the capacity of the poor for prevention and informed self-help and through human resource development of other people, partners and professionals that provide good back-up for both decentralization and participation.

b. Best practices of self-reliant reproductive health (care) as key area of concern and application for empowering people to take health and quality health care into their own hands; productive health (care) measures are added in the context of the macroeconomics and health debate.

- Security is supported and reinforced by:

a. Sustainable social sector reforms with a clear focus on good governance and stewardship, a strengthening of social institutions such as decentralization and participation, and a fair health care financing system aiming at solidarity.

b. Social health insurance that includes the care of catastrophic cases of the poor and indigents and that are based on a cost-effective high quality in health and hospital care and aimed at building up reasonable broader social security systems.

- Opportunities will thus be created in terms of human and social capital. This is an essential ingredient of economic growth, democratic development, cultural wealth, and human progress" (Schwefel 2002).

\section{International/global health is the leitmotiv of this decade}

There is a lot to do. And we can do a lot. It is easy and relatively cheap to reduce unnecessary suffering and escapable deaths in poor countries and populations. Prevention, self-help and quality health services in the context of social security schemes are essential: they could be supported by what had been recommended by physicians to the German Ministry for Economic Cooperation and Development: clear conceptions, exchange of experiences, quality assurance, safety concepts, social security systems, emergency aid, research, education, integration and reintegration (Wissenschaftlicher Beirat 2000). But this is certainly not enough; it is just the continuation of good but old-fashioned recipes. What is especially important is a drive towards "health in the hands of the people", i.e. empowerment for an educated responsibility for health and informed self-help, the so-called educationvaccine that is especially effective and efficient against HIV/AIDS, for example. It requires alliances with the education sectors. And it requires commitment (Schwefel 2001). Little money can save many lives and alleviate widespread suffering - a job for Sisyphus and not for large funds.

In and between rich countries an exchange of experiences is on the agenda. In Europe we could learn much from so many other European countries, not just from those that are being represented predominantly in English-speaking journals. Health system comparisons in the context of other social services abound; they should be taken into account when reforms are being prepared in a rush. The Spanish government-long ago, in 1984-invited many partners from all over the world, to consult its preparation of a new health law; even the government of Guatemala did something similar by the year 1999 in its health reform agenda (Proyecto 1999). In Europe and around the world, European health care has four fundamental and not yet fully used opportunities of exchange and development (Chanda 2001):

1. Cross-boundary consultation and therapy in selected disciplines, supported for example by telemedicine

2. Domestic care of foreign patients

3. Corporate presence abroad, especially in the areas of drugs, biotechnology and technical medical devices

4. Temporary migration of highly qualified personnel, especially for health system consultations in solidarity, subsidiarity, self-help and social market economy.

The health sector is a sector of economic growth with a strategically important potential.

\section{Globilization requires powerful ethics to gain a human face}

Intensive lobbying is needed to disseminate the growing knowledge that bodies and brains-health and education-are the main production factors of a pro-poor development strategy. Social marketing is needed to promote the basic idea that health and education need empowerment and security to create economic, social, cultural and democratic opportunities. The increasing globalization of civil pressure groups and their partnerships with other public-minded institutions of a global civil society should strengthen and empower the advocates of public goods and public health. Professional public health groups and associations and societies will be the main partners of this endeavour of globalizing information and ideas and trying to convert them into power. Cross-national and cross-institutional alliances are needed to promote the concept of brains and bodies as the backbone of development strategies. The globalization of the civil society "contribute to our freedoms", as Amartya Sen concludes (Sen 1999). Globalization is not just a threat, it is an opportunity to grasp.

Globalization driven only by market forces could and would be dangerous for all. Good governance, stewardship and ethics are needed most urgently today. These are traits of human beings and not of institutions. Excellent examples of personal stewardship exist at all levels of any 
society. The ethics of professionalism is a very important asset, indeed. Public health is not a fashionable label but a reminder of responsibility, for all its supporters and not just for those paid with tax money. Solicited or unsolicited, the representatives of governments and public institutions have to be checked by civil society alliances, to ensure they act in the public interest and according to the principles of the moral imperative: don't do to others what shouldn't be done to you.

\section{References}

Barrett R, Kuzawa CW, McDade T et al (1998) Emerging and reemerging infectious diseases: the third epidemiologic transition. Annl Rev Anthropol 27:247-271

Bloom DE, Canning D (2001) The health and poverty of nations: from theory to practice. Harvard University, Boston

Brundtland GH (2001) Opening message at the Fifth Meeting of the Commission on Macroeconomics and Health, http://www.who. int/director-general, Mexico City, 11 June 2001

Bundesministerium für wirtschaftliche Zusammenarbeit und Entwicklung (BMZ) (2001) Armutsbekämpfung - eine globale Aufgabe. Aktionsplan 2015: Der Beitrag der Bundesregierung zur weltweiten Minderung der Armut. BMZ, Bonn

Bundesministerium für wirtschaftliche Zusammenarbeit und Entwicklung (BMZ) (2002) Good governance. Internet publication of BMZ, http:/www.bmz.de, Bonn

Cabinet Office, Performance and Innovation Unit, United Kingdom (2001) Tackling the diseases of poverty. Meeting the Okinawa/ Millennium targets for HIV/AIDS, tuberculosis, and malaria, Cabinet Office, London

Chanda R (2001) Trade in health services. Commission on Macroeconomics and Health Working Paper, Geneva, www. cmhealth.org

Chen LC, Evans TG, Cash RA et al (1999) Health as a global public good. In: Kaul I, Grunberg I, Stern M et al (eds) Global public goods. International cooperation in the $21^{\text {st }}$ century. UNDP/Oxford University Press, New York, pp 284-304

Cornia GA (2001) Globalization and health: results and options. Bull World Health Organ 79:834-841

Fogel RW (1997) New findings on secular trends in nutrition and mortality: some implications for population theory. In: Rosenzweig MR, Stark O (eds) Handbook of population and family economics. Elsevier Science, Amsterdam

Fues T (2000) 20:20-Initiative und soziale Grunddienste im BMZHaushalt 2001. Studie im Auftrag des Arbeitskreises 20:20. Institut für Entwicklung und Frieden (INEF), Duisburg

G8 Information Centre (2000) G8 Communiqué Okinawa 23 July 2000. http://www.g7.utoronto.ca/g7/summit/index.htm

Global Fund to fight AIDS, Tuberculosis and Malaria (2003) www.globalfundatm.org

Gwatkin DR (2000) Health inequalities and the health of the poor. What do we know? What can we do? Bull World Health Organ 78:3-17

Gwatkin DR, Guillot M (2000) The burden of disease among the global poor. Current situation, future trends, and implications. World Bank for Global Forum for Health Research, Washington

Kassalow JS (2001) Why health is important to U.S. foreign policy. Milbank Memorial Fund \& Council on Foreign Relations, New York

Kaul I (2001) Global public goods and the poor. Development 44:77-84

McKeown T (1976) The modern rise of population. London (Arnold) 1976

Mies M (2001) Globalisierung von unten, Widerstand und neue Perspektiven. Initiative Kirche von unten, Frankfurt
Murray CJL, Lopez AD (eds) (1996) A comprehensive assessment of mortality and disability from diseases, injuries, and risk factors in 1990 and projected to 2020. The global burden of disease and injury series, vol. 1. Harvard University Press, Cambridge

Murray CJL, Frenk J (2000) A framework for assessing the performance of health systems. Bull World Health Organ 78:717731

Narayan D, Patel R, Schafft K et al (1999) Voices of the poor. Can anyone hear us? Voices from 47 countries. World Bank Poverty Group, Washington

Narayan D, Chambers R, Shah MK et al (2000) Voices of the poor. Crying out for change. Oxford University Press, New York

Nuscheler F (2001) Die Armen rebellieren nicht. Die Zeit 41

Organization for Economic Cooperation and Development (2001) DAC guidelines on poverty reduction. OECD, Paris

Organization for Economic Cooperation and Development (OECD) (2001) Peer review. Review of the development co-operation policies and programme of Germany, OECD, Paris

Peters DH, Yazbeck AS, Wagstaff A et al (2002) Better health systems for India's poor. Findings, analysis, and options. World Bank, Washington

Proyecto de Apoyo a la Reforma del Sector Salud en Guatemala (1999) Foro international. La reforma del sector salud, Comisión Europea, Guatemala

Reich MR (2002) Introduction: Public-private partnerships for public health. In: Reich MR (Ed) Public-private partnerships for public health, Harvard University Press, Cambridge, pp 118

Sachs J (2001a) Pathways from public health to economic development. Mimeographed paper 12.5.2001

Sachs J (2001b) The links of public health and economic development, Office of health economics, London

Sachs J, Ahluwalia IJ, Amoako KY et al (2001) Macroeconomics and health: investing in health for economic development. Report of the commission on macroeconomics and health, WHO, Geneva

Sachs J (2002) An economist's view of health. Interview. Bull World Health Organ 80:167-169

Saltman RB, Ferroussier-Davis O (2000) The concept of stewardship in health policy: Bull World Health Organ 78:732-739

Schwefel D (2001) Páginas del PAPS. Aportes de la Cooperación Alemana al Desarrollo (GTZ) al Programa de Atención Primaria de Salud (PAPS) del Ministerio de Salud Pública y Asistencia Social de Guatemala. GTZ, Guatemala

Schwefel D (2002) Public Health aus globaler Sicht. Ökonomisch benachteiligte, nichteuropäische Länder. In: Schwartz FW, Badura B, Busse R et al (eds) Das Public Health Buch. Gesundheit und Gesundheitswesen. Urban \& Fischer, München, pp 15-20, 830-831

Schwefel D (2002) Global commitment to poverty reduction. What does it imply for donors, partner countries and other actors active in the health sector? A "from within the health sector" perspective of a senior GTZ professional. http:// www.doh. gov.ph/gtzhealth/downloads, Manila

Schwefel D (2003) Emerging food-related health problems in globalization. In: Schulz M, Kracht U (eds) Food and nutrition security, St. Martin's Press, New York (in press)

Sen A (1999) Global justice. Beyond international equity. In: Kaul I, Grunberg I, Stern M et al (eds) Global public goods. International cooperation in the $21^{\text {st }}$ century, Oxford University Press, New York, pp 116-125

Sen A (1999) Health in development. Bull World Health Organ 77:619-623

State Failure Task Force (1999) State Failure Task Force report: phase II findings. In: Environmental change and security project report 5:49-72

United Nations, General Assembly, Fifty-fifth Session (2000) United Nations Millennium Declaration (18 September 2000), United Nations, New York 
United Nations (2000) We the peoples: the role of the United Nations in the twenty-first century. The Millennium Report, 2000, United Nations, New York

Vandemoortele J (2001) Social policies and investment in health. Development 44:44-50

Wissenschaftlicher Beirat beim Bundesministerium für wirtschaftliche Zusammenarbeit und Entwicklung (1999) Globalisierung und Entwicklungszusammenarbeit, BMZ, Bonn

Wissenschaftlicher Beirat beim Bundesministerium für wirtschaftliche Zusammenarbeit und Entwicklung (BMZ) (2000) Gesundheit und Entwicklungszusammenarbeit am Beginn des 21. Jahrhunderts, BMZ, Bonn
Wolfensohn JD (2000) Foreword. In: Narayan D, Chambers R, Shah MK et al (eds) Voices of the poor. Crying out for change. Oxford University Press, New York, pp xv-xvi

World Bank (1997) Health, nutrition and population strategy paper. IBRD, Washington

World Bank (2001) World Development Report 2000/2001. Attacking poverty. Oxford University Press, Washington

World Health Organization (1998) Emerging and re-emerging infectious diseases (Fact Sheet No. 97, Revised August 1998). WHO, Geneva

World Health Organization (2001) The World Health Report 2001. Mental health: new understanding, new hope. WHO, Geneva 